\title{
Characterization of Environmental Impact of Building Materials for the Purpose of Ecodesign
}

\author{
Agnese Skele ${ }^{1}$, Mara Repele ${ }^{2}$, Gatis Bazbauers ${ }^{3},{ }^{1-3}$ Institute of Energy Systems and Environment, Riga Technical \\ University
}

\begin{abstract}
The building material manufacturing sector is one of the sectors with the highest consumption of fossil fuel resources. The "cradle-to-gate" study of the ceramic bricks made in the Āne plant of JSC Lode, Latvia, is performed according to ISO standards 14044:2006. Life cycle inventory data have been collected at the factory site. Three different perspectives of the "Eco-Indicator'99" method are used to conduct an environmental characterization of the building materials to obtain the total impact indicator.
\end{abstract}

Keywords - brick production, cradle-to-gate, ecodesign, environmental characterization of bricks

\section{INTRODUCTION}

As mentioned in the report drawn up by the Working Group for Sustainable Construction with participants from the European Commission, Member States and Industry [1] and in the final report of sustainable construction (European Monitoring Centre on Change), "The construction industry is Europe's largest industrial employer. Construction activities consume more raw materials than any other industrial sector, while the built environment accounts for the largest share of greenhouse gas emissions in terms of energy end-use. Because of this, the construction industry faces a considerable environmental challenge, bigger than any other industrial sector" [2].

Brick is a block of ceramic material and is mainly used for the construction of walls in any kind of buildings - residential, commercial, and industrial. A huge amount of energy is necessary to make a baked brick. Saving energy resources in this sector would reduce the total environmental impact caused because of decreasing energy demand. Manufacturing bricks in high-efficiency kilns is common in all developed countries and in some developing countries. However, there are countries in Asia that still manufacture bricks in the traditional way which is low-efficient [3]. For each country, especially for the developing countries, it is a challenge to turn this sector to the sustainable manufacturing methods, including the establishment of modern brick baking kilns [3].

The largest producer of the ceramic building materials in the Baltic countries is the Joint Stock Company (JSC) Lode. The company was established in 1958 and now it owns four plants located in Liepa, Kalnciems, Āne and Līvāni [4]. The "cradle-to-gate" study was performed for the ceramic bricks made in the Āne plant of JSC Lode.

A very important aspect in promoting sustainability in building sector is the eco-labelling of the building materials. Recognizable and respectable labels can be a sign of competitiveness for the manufacturers. These labels list each product's contribution to global warming, ozone depletion, acid rain, habitat loss and a handful of other environmental indicators. Eventually, whole buildings can be measured based on their performance against a similar set of indicators. This labelling rating system is a result of an environmental lifecycle assessment (LCA). The LCA procedure is new in Latvia which is a very important reason for this particular study.

\section{METHODS}

Plouffe et al. came to a conclusion that one of the most widely used tools used for ecodesign is life cycle analysis (LCA) [5]. LCA is a scientifically based methodology that is used to assess the environmental performance of the product, to recognize the problems and to start solving them. The increasing interest in the counteracting of global warming and in environmentally friendly building materials also raises the interest of producers in the eco-labelling of their products. Eco-labels help society to choose materials with the best environmental performance.

This study is made by following ISO standard 14044:2006, which describes the four main evaluation procedures: (1) the goal and scope definition, (2) the life cycle inventory analysis, (3) life cycle impact assessment, and (4) interpretation [6, 7].

The LCA software "SimaPro 7.2." (Faculty version) was used to model environmental impacts caused during a product's life-cycle [8].

The data that are used in the present LCA study consist of:

- raw data that were provided by the brick production plant in Āne, Latvia;

- calculated data which are based on bibliographical information.

The three cultural perspectives defined in the "EcoIndicator'99" methodology [9] are used to conduct an environmental characterization of the building materials to obtain the total impact indicator. Each one takes a different perspective on how to consider the potential damage from a particular substance. Marceau, VanGeem [10] and DeSchryver [11] describe all three cultural perspectives:

The egalitarian perspective takes an extremely longterm look at substances if there is any indication that they have some effect. This view has strong group cohesion (relationships) coupled with few regulations and considers nature to be fragile and unstable. This perspective gives high priority to the precautionary principle and equal importance to present and future effects. 
- The hierarchic perspective takes a long-term look at all substances if there is consensus regarding their effect. This perspective is characterized by strong group cohesion with binding regulations for social relations and considers nature to be in equilibrium. This view coincides with the view that impacts can be avoided with proper management and the search for a balance between manageability and the precautionary principle.

- The individualist perspective takes a short-term look (100 years or less) at substances if there is complete proof regarding their effect. This view is characterized by weak group cohesion and regulations for social relations, and considers nature to be stable and able to recover from any disturbance. This last perspective coincides with the view that humans have a high adaptive capacity through technological and economic development. The individualist perspective considers known damages as the most reliable basis for decisions and emphasizes present effects over future gains or losses.

\section{LIFE CYCLE ASSESSMENT}

\section{A. Goal and Scope Definition}

The main goal is to calculate and assess the environmental impact of the manufacturing process of clay bricks in the Āne factory of Latvia, especially in terms of energy consumption and greenhouse gas emissions, which is linked directly to the brick manufacturing stage. The research was conducted to compare the environmental impact of bricks and other building materials, as well as to compare the environmental load of bricks made in Latvia with those made in other factories outside Latvia.

LCA is needed in order for Latvian-produced building materials to be competitive on the European market. It is also associated with reductions of carbon emissions in the future, and with growing concerns about global warming from stakeholders. In addition, this study is to start building a Latvian construction life-cycle inventory database and determining the production stages with the greatest environmental impacts, the stages in which improvements are required.

The product system consists of a variety of products entering and leaving the system. Different raw materials (mainly clay) and various combustible additives, such as straw and sawdust, as well as natural gas, which is used for the manufacture of the required heat and electricity, are used in brick production. Outgoing products of the product system are mostly air emissions resulting from the combustion of natural gas. The manufacturing process results in a small amount of domestic waste, water and solid waste, but the amount of waste is very small and the effects are considered minor and hereby not included in this study.

\section{B. Functional Unit and Reference Flow}

The brick production plant produces more than one building material type which is made of ceramic clay. These types differ in weight and dimensions. For the purposes of the present study, one ton of a specific type of brick has been chosen as a functional unit.

The reference flow is a ton of bricks.

\section{System Boundaries}

The clay brick system boundaries included clay extraction, storage and processing, shaping, drying and firing of bricks, and packaging. The complete system investigated is shown in Figure 1.

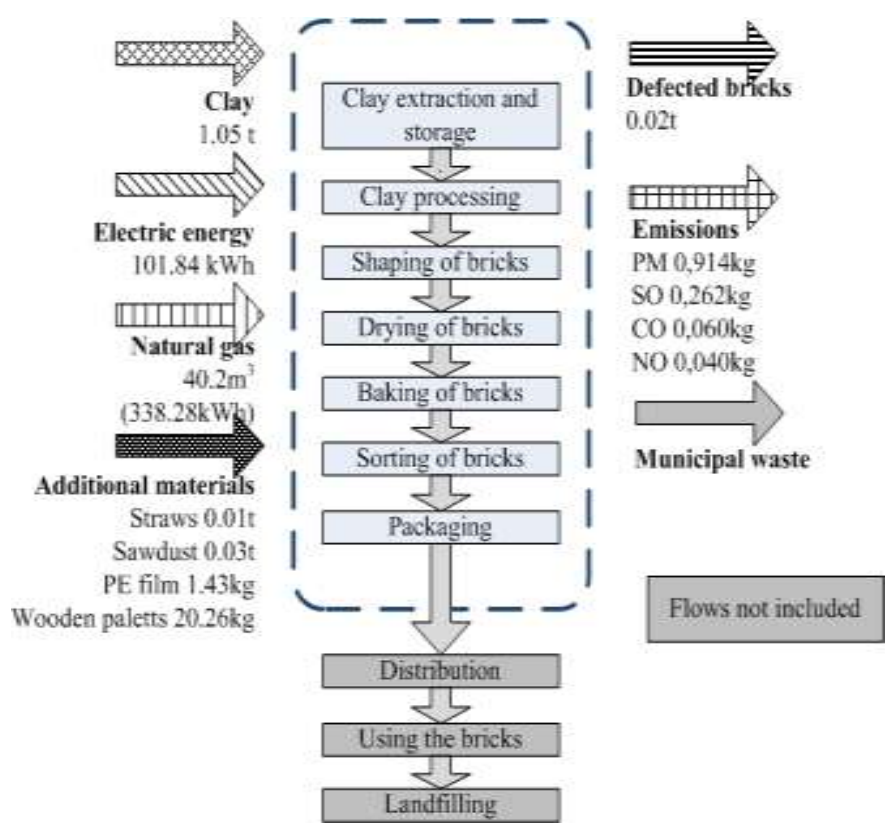

Fig. 1. Schematic presentation of the investigated system.

The life cycle is divided into the following subsystems:

1. Raw material acquisition and storage: The raw material used for the production of bricks is clay, which is transported to the factory by trucks. Clay is extracted from the clay mine which is located at a distance of $1.5 \mathrm{~km}$ from the brick factory. The basic clay found in this mine is of the Quaternary Period. Extracted clay is stored in cones. Storage in cones for minimum eight months provides the natural reduction of moisture. The volume of cones is approx. 10000 $\mathrm{m}^{3}$.

2. Clay processing: Clay which has lied the necessary eight months in the cones is taken by a single-bucked excavator and sacked into a processing machine. After the processing machine, the clay is delivered to a running-mill along a conveyer. From the mill, the clay is transported through cylinders with a gap of 3 and $1 \mathrm{~mm}$. After such processing, the clay is stored in a reservoir with a volume of approx. $1500 \mathrm{~m}^{3}$. The processing rate is $400 \mathrm{~m}^{3}$ of clay per twenty-four hours. Clay is taken from the reservoir by a double-bucked excavator and delivered to a raspler where combustible additives, which are sawdust and straws, are also added. 
3. Shaping of bricks: After processing, the clay mass is delivered to a screw-type press where it is shaped and cut to form bricks.

4. Drying: The shaped bricks are automatically placed on drying palettes and transported into a drying camera. The temperature in the drying camera is approx. $140^{\circ} \mathrm{C}$. Hot air is drawn from a baking furnace for drying. The bricks contain 2$4 \%$ of the initial moisture after the drying process.

5. Firing: After the drying camera, the bricks are automatically placed on baking palettes which are transported into the baking furnace every 30-35 minutes. The bricks are baked at the maximum temperature of $950-980^{\circ} \mathrm{C}$. Natural gas is used as the fuel in the furnace.

6. Packaging: The baked bricks are placed on wooden pallets and wrapped in polyethylene (PE) film.

TABLE 1

INVENTORY DATA

\begin{tabular}{|l|l|l|}
\hline Name & Amount per month & Unit \\
\hline Extracted clay & 8600 & $\mathrm{~m}^{3}$ \\
\hline Electric energy & 831 & MWh \\
\hline Natural gas & 328 & thousand $\mathrm{m}^{3}$ \\
\hline Bricks produced & 8160 & $\mathrm{t}$ \\
\hline PE film & 1.2 & $\mathrm{~kg} / \mathrm{m}^{3}$ \\
\hline Defected bricks & 2 & $\begin{array}{l}\% \text { of all production } \\
\text { amount }\end{array}$ \\
\hline Particulate matter $(\mathrm{PM})$ & 7.46 & $\mathrm{t}$ \\
\hline SO & 2.14 & $\mathrm{t}$ \\
\hline CO & 0.49 & $\mathrm{t}$ \\
\hline NO & 0.32 & $\mathrm{t}$ \\
\hline Wooden palettes & 17 & $\mathrm{~kg} / \mathrm{m}^{3}$ \\
\hline Straws & 0.9 & $\%$ of all mass \\
\hline Sawdust & 2.7 & $\%$ of all mass \\
\hline
\end{tabular}

\section{Life Cycle Inventory}

Table 1 presents the overall results of production for one month. Figure 1 presents the input and output flows for the production of one ton of ceramic bricks. Clay processing is a large energy consuming process of the life cycle. During the clay processing, $40.74 \mathrm{kWh}$ of electric energy are consumed, which constitutes $40 \%$ of all electrical energy that is used in the manufacturing process.

The baking process is the most energy consuming process of the studied brick production processes. Due to natural gas consumption, $338.28 \mathrm{kWh}$ of primary energy are consumed. There are also $25.46 \mathrm{kWh}$ of electricity used during the process.

Natural gas is the main energy source in brick production. The use of natural gas and combustive additives contributes to $\mathrm{SO}, \mathrm{CO}$ and $\mathrm{NO}$ production.

\section{E. Impact Assessment}

The emissions of the system have been grouped into impacts (characterization step based on the Eco-Indicator'99 method) [8]. The Eco-Indicator'99 is one method of the aggregation (or, as described in ISO draft 14042, "weighting through categories") that leads to a single score.

Six impact categories were considered: carcinogens, respiratory inorganics, climate change, ecotoxicity, acidification / eutrophication and fossil fuels. Table 2 summarizes the results from the characterization of the impacts for the chosen functional unit according to three perspectives.

TABLE 2

CHARACTERIZATION RESUltS

\begin{tabular}{|l|l|l|l|l|}
\hline Impact category & Unit & H/A & I/A & E/A \\
\hline Carcinogens & DALY & $3.54^{-5}$ & $1.68^{-6}$ & $3.54^{-5}$ \\
\hline Respiratory inorganics & DALY & $1.59^{-4}$ & $1.02^{-4}$ & $1.59^{-4}$ \\
\hline Climate change & DALY & $2.93^{-5}$ & $2.8^{-5}$ & $2.93^{-5}$ \\
\hline Ecotoxicity & PAF*m2yr & 11.8 & 0.601 & 11.8 \\
\hline Acidification/ Eutrophication & PDF*m2yr & 1.73 & 1.73 & 1.73 \\
\hline Fossil fuels & MJ surplus & 245 & - & 168 \\
\hline
\end{tabular}

The environmental score of each effect is calculated based on the simple formula (1):

$$
E S=C V * N F * V F
$$

where ES - environmental score; $\mathrm{CV}$ - characterized value; $\mathrm{NF}$ - normalization factor; VF - valuation factor [12].

TABLE 3

NORMALIZATION FACTORS

\begin{tabular}{|l|l|l|l|}
\hline Perspective & $\begin{array}{l}\text { Human } \\
\text { Health }\end{array}$ & $\begin{array}{l}\text { Ecosystem } \\
\text { Quality }\end{array}$ & Resources \\
\hline Hierarchist (H/A) & 65.1 & $1.95^{-4}$ & $1.19^{-4}$ \\
\hline Individualist (I/A) & 121 & $2.22^{-4}$ & $6.77^{-3}$ \\
\hline Egalitarian (E/A) & 64.7 & $1.95^{-4}$ & $1.68^{-4}$ \\
\hline
\end{tabular}

Weighting factors are applied in order to scale the seriousness of the results measured in indicator points. The normalization and valuation weighting factors used for the purpose of this study are shown in Tables 3 and 4 [13]. In the final step, valuation scores are added up to give a total impact.

TABLE 4

WEIGHTING FACTORS

\begin{tabular}{|l|l|l|l|}
\hline Perspective & $\begin{array}{l}\text { Human } \\
\text { Health }\end{array}$ & $\begin{array}{l}\text { Ecosystem } \\
\text { Quality }\end{array}$ & Resources \\
\hline Hierarchist (H/A) & 400 & 400 & 200 \\
\hline Individualist (I/A) & 400 & 400 & 200 \\
\hline Egalitarian (E/A) & 400 & 400 & 200 \\
\hline
\end{tabular}

\section{Results}

Figures 3 and 4 illustrate the results extracted during the previous stages. 
The total impact indicator of the brick "cradle-to-gate" cycle is $11.9 \mathrm{Pt}$, when using the Hierarchist perspective, and 11.7 $\mathrm{Pt}$ and $6.95 \mathrm{Pt}$ respectively by the Egalitarian and Individualist perspective.

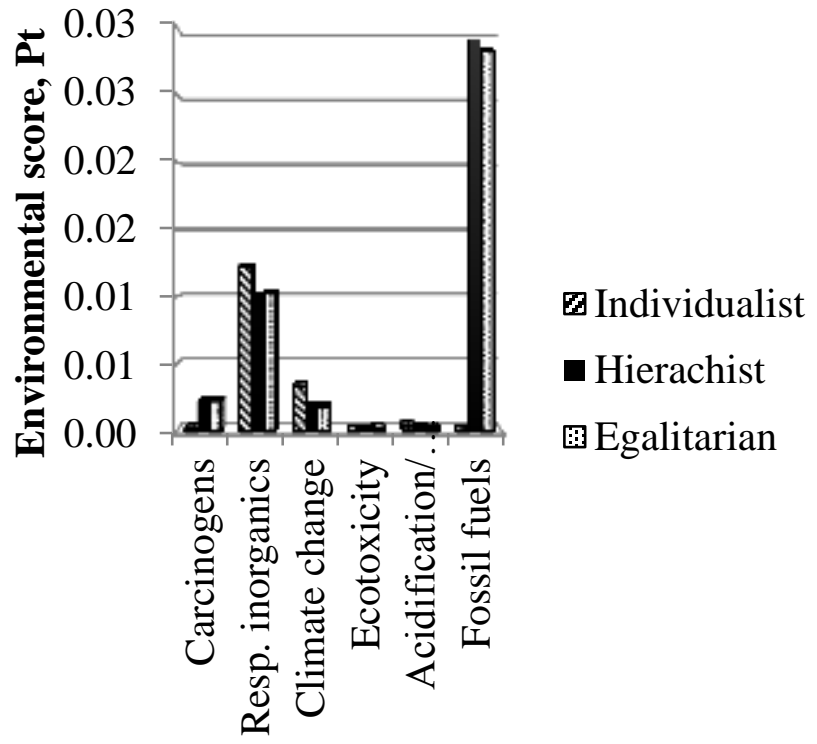

Fig.3. Normalized scores.

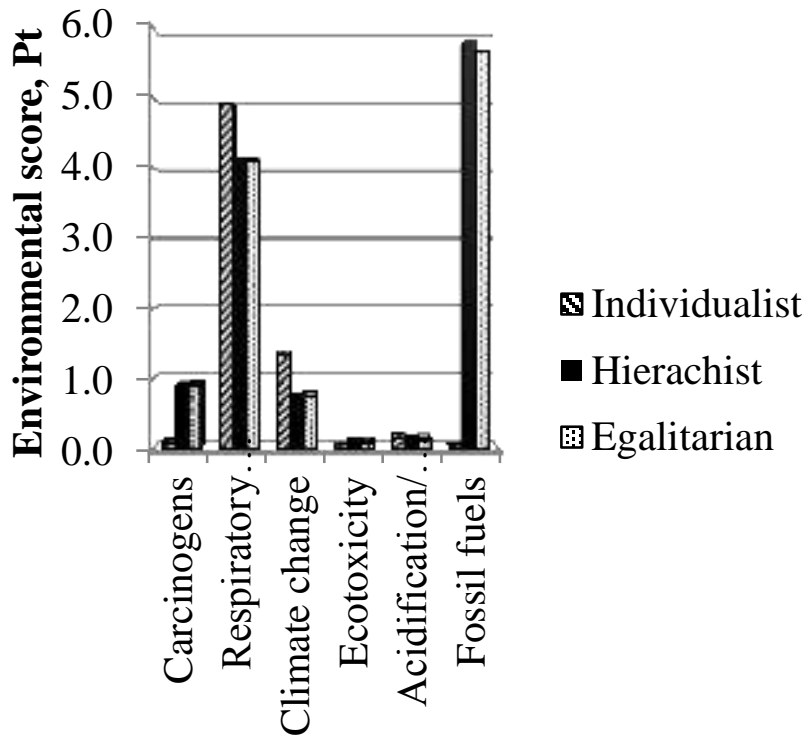

Fig.4.Weighted scores.

The standard Eco-indicators 99 can be regarded as dimensionless figures. The scale is chosen in such a way that the value of one point is representative for one thousandth of the yearly environmental load of one average European inhabitant [9]. The absolute value of the points is not very relevant, as the main purpose is to compare relative differences between production processes. Environmental impact of the brick life cycle can be compared with that of the alternative solutions for the construction of walls considering also the fulfilled function, e.g. with gypsum boards, in order to improve the environmental performance of buildings.

The highest value of environmental impact (Fig. 5) is for the firing process for all three different perspectives. The main contributor to the impact is the usage of natural gas for the industrial baking furnace. Relatively important processes from the environmental point of view are also clay processing, sorting and packaging. During the clay processing, a large amount of electricity is used, but for the brick packaging, polyethylene film is used which plays an important role in the impact to the environment.

The main contributing impact categories from the point of view of all three different perspectives are shown in Fig. 6. The highest value of the effect to the environment goes to the impact category of fossil fuels which is explained mainly by the usage of natural gas. The second important impact category which is affected by the brick production is respiratory inorganics. This is mainly due to the fact that bricks are baked in the industrial furnace where natural gas is combusted. Electricity consumption also contributes to this impact category since production of electricity causes large amounts of emissions. Due to the fact that the average European type of electricity mix is used in this study, it does not reflect the true electricity mix in Latvia. Hydro power plants produce a large share of electricity in Latvia and, thus, the share of renewable energy sources in power production is nearly $50 \%$.

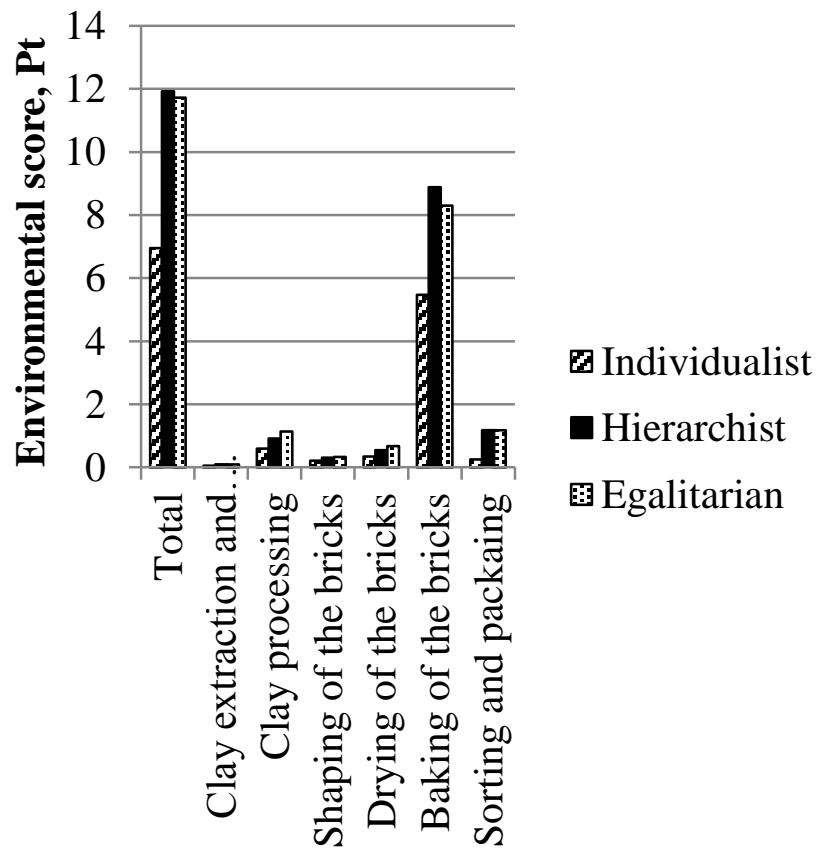

Fig.5. Impact of the production processes. 


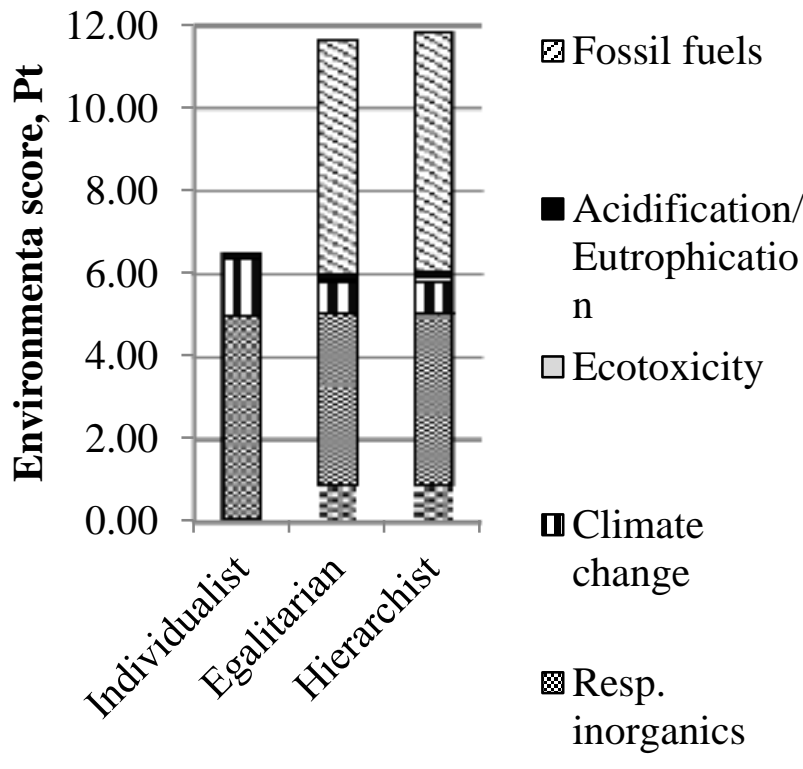

Fig.6. Main contributing impact categories

\section{V.CONCLUSIONS}

The "cradle-to-gate" study conducted in the process of brick production indicated that this process is very energy intensive. Most of the emissions to the environment are attributed to energy use, directly at the site with the combustion of natural gas, and also indirectly with the use of large amounts of electricity. When it comes to the effect of the environmental impacts, the fossil fuels and respiratory inorganics have the highest values.

Although natural gas is one of the cleanest fossil fuels, using the renewable energy resources would reduce the total impact to the environment of the brick production process. The use of local renewable resources would also increase energy independence in Latvia, thus reducing dependence on imported gas.

The total energy consumption to produce one ton of bricks is by $140 \mathrm{kWh}$ (which is $24 \%$, respectively) less than to produce one ton of bricks in Greece [12] where pet-coke and diesel is consumed.

There have been other studies conducted regarding brick production impact to the environment, for example, in Australia [14] and Italy [15], but the final eco-indicators as single scores for one ton of bricks, which could be useful to compare the results attained in this study, were not determined herewith.

In the study about the bricks produced in Greece, the EcoIndictor 95 method is used. Therefore, the results can be compared only partly, because in this study, which is conducted on bricks manufactured in Latvia, the Eco-Indicator 99 method is used. These two above mentioned methods differ from each other mainly due to the fact that the Eco-Indicator 99 method is the updated version of the Eco-Indicator 95 method and that means that the results of the Eco-indicator 99 method may be more accurate. The single scores cannot be compared, but the impact categories on the global scale can be viewed. The main impact categories in the LCA study of the brick production impact in Greece using Eco-Indicator 95 are acidification $(56.19 \%)$, winter smog $(30.26 \%)$, greenhouse effect $(11.62 \%)$, eutrophication $(1.6 \%)$ and summer smog $(0.33 \%)$. However, according to the study of bricks produced in Latvia, the main impact category which stands out is the depletion of fossil resources. This result is only logical regarding the main energy source - natural gas used in the brick baking process in Latvia. But the acidification category takes only the $5^{\text {th }}$ place. In the study for the Greece conditions, no impact category is related to fossil fuels, although they use pet-coke and diesel in the production processes.

Although the brick production process in Greece and Latvia are almost the same (only the fuels used differ), there still remains a great difference in the results when using two impact assessment methods Eco-Indicator 95 and EcoIndicator 99.

The greatest impact on the environment from processes is associated with energy consumption. The manufacturer has to think about how to use the available resources and resources necessary for the production effectively, as well as to look for opportunities and ways to use a variety of waste products to produce new products without compromising on quality and technical characteristics of the product. The manufacturer also has to consider how to improve some qualities of the product while reducing the new primary resource exhaustion.

One of the recommendations could be to use more of the combustible additives derived as waste from the production processes of other products. Moreover, replacing natural gas with some alternative energy source, such as biogas, would reduce the total impact on the environment. Since the factory is huge enough and the amount of necessary electrical energy is also considerable, the co-generation opportunity is one of the possible ways of reducing the impact to the environment and decreasing the factory's dependence on the external energy suppliers.

\section{REFERENCES}

1. Competitiveness of the Construction Industry. An Agenda for Sustainable Construction in Europe, 2001, p.7.

2. Sustainable Construction - final report [Online]. - [Accessed 09.08.2011.]. Available:

http://www.eurofound.europa.eu/emcc/content/source/eu04019s.htm ?p1=sector\&p2=Construction_and_Woodworking

3. Gomes, E., Hossain, I. Transition from traditional brick manufacturing to more sustainable practices. Energy for Sustainable Development, 2003, vol. 7, Nr.2, p.66. - 76.

4. JSC "LODE" Plants [Online]. - [Accessed 09.08.2011.]. Available: www.lode.1v

5. Plouffe, S., Lanoie, P., Berneman, C., et.al. Economic benefits tied to ecodesign. Journal of Cleaner Production, 2011, Nr.19, p. 573.579.

6. International Standard ISO 14044. Environmental management - life cycle assessment - Requirements and guidelines International. 2006.

7. International Standard ISO 14040. Environmental management life cycle assessment - Principles and Framework. 2006.

8. SimaPro [Online]. - [Accessed 29.07.2011.]. Available: www.pre.nl

9. Goedkoop, M., Spriensma, R. The Eco-indicator'99. A damage oriented method for Life Cycle Impact Assessment. Methodology Report. Pré Consultants B.V., 2001. Available: www.pre.nl

10. Marceau, M.L., VanGeem, M.G. Life Cycle Assessment of an Insulating Concrete from House Compared to a Wood Frame House. 
$R \& D$ Serial No. 2571, Portland Cement Association, Skokie, Illinois, USA, 2002, p. 12.

11. DeSchryver, A.M. Value choices in life cycle impact assessment. Ph.D. thesis. Radboud University, Nijmegen, 2010,. p. 7.-10., 101.

12. Koroneos, Ch., Dompros, A. Environmental assessment of brick production in Greece. Building and Environment, 2007, Nr.42, p. 2114.-2123.

13. Sima Pro Faculty version, database.

14. Bealiba V. Report on Life Cycle Assessment for geobrick. GeoBrick and Sustainability Victoria 2010.

15. Torricelli M., Gargari C., Palumbo E. The life cycle assessment of Italian clay brick products. Sustainable Building 2007, 319. - 328.

Agnese Skele, Msc. env., Riga Technical University, Institute of Energy Systems and Environment

Address: Kronvalda bulv.1, LV-1010, Riga, Latvia

Phone: +371 27000706

E-mail: agnesesk@gmail.com

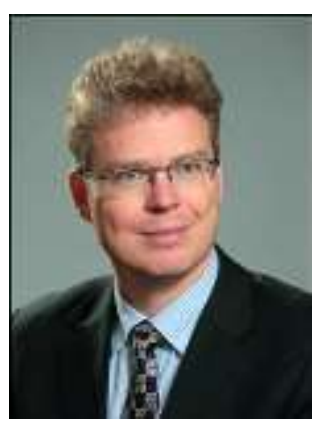

Gatis Bazbauers, Dr.sc.ing., has a diploma of thermal engineering (1990), master of science degree in mechanical engineering (1995), doctor of science degree in engineering (1999) and bachelor's degree in business administration (2002). He works in the Institute of Energy Systems and Environment, Faculty of Energy and Electrical Engineering at Riga Technical University from the year 2000, and currently is a Professor. He worked as a Managing Director in the energy company "Vattenfall Latvia" (1995-2007), as a Project Manager in

the energy consulting company "EEE" (1992-1993) and as an Assistant in the Riga Technical University (1990-1993). The main research interests are district heating systems and cogeneration, energy system planning and economics, renewable energy sources, ecodesign, life cycle assessment. Gatis Bazbauers is a member of the council of Latvia's District Heating Association.

Phone: +371 67089911

E-mail: gatis.bazbauers@rtu.lv

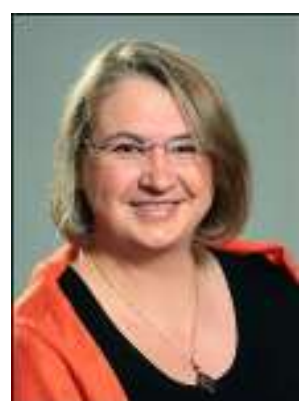

Mara Repele, PhD student of the Institute of Energy Systems and Environment at Riga Technical University, has Master Degree in Geology (2004) and Master Degree in Environmental Science (2009). The main field of study is ecodesign and life cycle assessment of building materials. Mara Repele currently works as a Forensic Scientist at the Biological and Chemical Investigation Department at the State Forensic Science Bureau, 55 Hospitalu Street, Riga, Latvia. Previously she worked as a Geologist at the Institute of Geology and as a Technician at the Laboratory of Rock Research at the University of Latvia. Mara Repele received the Letter of distinction of the Rector of the University of Latvia for researches in geology (2004) and Werner von Siemens Excellence Award for Master's thesis "Development of method for ecodesign" (2009).

E-mail: mara.repele@rtu.lv

Agnese Šķēle, Māra Rēpele, Gatis Bažbauers. Būvmateriālu ietekmes uz vidi raksturojums ekodizaina vajadzībām.

Pētījumā ir analizēts māla kieǵelu ražošanas process Latvijas būvmateriālu ražotnē, apkopoti ražošanas procesa inventarizācijas dati un, izmantojot dzīves cikla ietekmes modelēšanas programmatūru „SimaPro”, veikts ķieǵeḷu ražošanas procesa ietekmes uz vidi raksturojums. N̦emot vērā to, ka rezultātus paredzēts izmantot ekodizaina vajadzībām, ietekmes uz vidi raksturojums veikts, izmantojot dzīves cikla ietekmes nov ērtējuma metodi $E c o-$ Indicator'99 un tās trīs kultūras perspektīvas - hierarhista, egalitariāna un individuālista perspektīvas. Darba galvenais mērkkis ir aprēḳināt un novērtēt Latvijā ražotu ķieǵeļu ietekmi uz vidi īpaši saistībā ar enerğijas patēriņu un siltumnīcas efektu izraisošo gāzu emisijām, ka s saistīta tieši ar ķieğeḷu ražošanas posmu, lai varētu veikt ekodizainu. Pētījums veikts keramisko būvmateriālu dzīves cikla izejvielu ieguves un ražošanas posmiem. Papildus šī pētījuma mērķis ir sākt veidot Latvijas būvmateriālu dzīves cikla inventarizācijas datu bāzi un iespējams noteikt posmus, kuros veidojas vislielākā ietekme uz vidi un, kuros ir nepieciešami uzlabojumi. 